\title{
Predicting Students' First-Year Academic Performance Using Entry Requirements for Faculty of Science in Kaduna State University, Kaduna - Nigeria
}

\author{
Sa'adatu Abdulkadir ${ }^{*}$, Francisca Nonyelum Ogwueleka \\ Department of Computer Science, Nigerian Defence Academy, Kaduna, Nigeria \\ Email address: \\ saa.abdul@ymail.com (S. Abdulkadir),ogwuelekafn@gmail.com (F. N. Ogwueleka) \\ ${ }^{*}$ Corresponding author
}

To cite this article:

Sa'adatu Abdulkadir, Francisca Nonyelum Ogwueleka. Predicting Students' First-Year Academic Performance Using Entry Requirements for Faculty of Science in Kaduna State University, Kaduna - Nigeria. American Journal of Computer Science and Technology.

Vol. 2, No. 1, 2019, pp. 9-21. doi: 10.11648/j.ajcst.20190201.12

Received: June 10, 2019; Accepted: July 5, 2019; Published: July 22, 2019

\begin{abstract}
The study aimed to determine if any of the entry requirements such as Ordinary Level (OL) results, Unified Tertiary Matriculation Examination (UTME) scores or Post-UTME (PUTME) scores could predict an outstanding academic performance of first-year undergraduate students admitted into the Faculty of Science in the Kaduna State University, Kaduna. The study adopted the descriptive research design. A purposive sample of nine hundred and forty-three (943) first-year students constituted the population for the study were drawn from Computer Science, Mathematics and Physics undergraduate degree programmes from the Faculty of Science of the university who were admitted from the 2010/2011 to 2014/2015 academic sessions. The instruments for data collection were OL, UTME and first-year Cumulative Grade Point Average (CGPA) results, which were coded and analysed with the aid of Computational Statistical Package for Social Sciences (SPSS). Pearson Product Moment Correlation (PPMC) Coefficient and Multinomial Logistics Regression (MLR) were the statistics used to answer the four research questions used. The results revealed that with a weak correlation, OL is a good predictor on the CGPA, a dependent variable, for academic performance which holds true for students who are in the CGPA category of '1st class' and '2nd Class Lower' respectively. It concluded that the use of OL and UTME as instruments is not enough to select candidates for admission and therefore recommended that other instruments such as senior secondary school mock examinations need to be included as part of the entry requirements in the admission criteria.
\end{abstract}

Keywords: Ordinary Level, Unified Tertiary Matriculation Examination (UTME), Post-UTME, Students, Prediction, Academic Performance, Entry-Level

\section{Introduction}

Education is an essential issue regarding the development of any country in the world. It is a progressive development of knowledge and skills of examinees through stages of teaching and learning at various levels [1]. In Nigeria, the demand to acquire university education has been on the increase than ever before [2] due to the increase in the population of graduates from secondary schools [3]. The number of undergraduate population in Nigerian Universities has increased from 103 in 1948 to an estimated population of 600,000 in 2018 [4].

At the inception of the Kaduna State University (KASU) in 2005, a total number of 409 students were admitted out of which 199 were for the Faculty of Science. In the 2017/2018 academic session, a total number of students admitted was 4,031, and 1,632 was admitted into the Faculty of Science.

Students admitted into any of the Faculty of Science undergraduate degree programmes in the Kaduna State University must have been subjected to serious academic scrutiny. Each student is expected to have at least five credit passes in not more than two sittings in Mathematics, English Language and three other science-based subjects such as Chemistry, Biology, Physics and Geography at the Ordinary 
Levels (OL) of either Senior School Certificate Examination (SSCE) which is conducted by West Africa Examination Council (WAEC) and National Examination Council (NECO). Also, each student is expected to have obtained at least the minimum score required in the Unified Tertiary Matriculation Examination (UTME), conducted every year by the Joint Admissions Matriculation Board (JAMB) since 1979. Despite all these, some students perform poorly in their studies during the first year while some perform very well.

In order to accomplish and improve the value of education, it is necessary to find other ways to enhance the academic performance of students. The emphasis on academic performance, which is also dominant worldwide, has encouraged many studies about the conditions that promote it. There have been various perspectives presented by researchers and psychologists about what is academic performance and its importance.

In Nigerian universities, an academic performance frequently is defined in connection with semester examination performance. In this study, the academic performance is categorised by the entire performance each year, which culminates in a Cumulative Grade Point Average (CGPA). The CGPA score takes into consideration students' tests, assignments, practicals, examinations and sometimes lecture attendance. Formula 1 is used for calculating the CGPA.

$$
\text { CGPA }=\frac{\text { Sum of all registered courses in all semesters of study (Credit Units } \times \text { Grade Points) }}{\text { Total number of Credit Units registered in all semesters of study by student }}
$$

Most universities in Nigeria have been using 5.0 as their perfect CGPA score. However, in September 2015, the grading system in the Nigerian University System was reviewed by the National Universities Commission (NUC) and its relevant stakeholders such as the Vice-Chancellors, Deputy Vice-Chancellors, academics as well as Directors of Academic Planning of various Nigerian universities [5]. The stakeholders agreed that the Pass Degree be abolished from the grading system and the lowest and highest CGPA scores are 0.00 and 4.00 respectively effective from the 2016/2017 academic session which implies that as long as the score is high, the better the academic performance of the students. As such, the CGPA is considered to be a good predictor indicator of a student's academic performance.

Prediction and analysis of students' overall academic performance is a vital milestone in an educational environment that builds their future. Reference [6] stated that students' academic performance is not only dependent on various factors such as personal, socio-economic, psychological and other environmental variables but also quite challenging.

The focus of this study is to predict full-time undergraduate students' first-year Cumulative Grade Point Average (CGPA), which is one of the variables for measuring the academic performance by using entry requirements, such as Ordinary Levels and UTME, for Faculty of Science in Kaduna State University (KASU), Kaduna - Nigeria.

The rest of this paper is organised as follows: section 2 is the review of related literature, section 3 presents the methodology, section 4 discusses the results obtained, and the last section presents the conclusion and recommendation.

\subsection{Statement of the Problem}

Over the years in Nigerian tertiary institutions, there has been rife with complaints about students' poor academic performance. Students' academic records show that after admissions, some students perform poorly even after going through a series of screening of their OL results, and writing of UTME and PUTME examinations before offering them admissions. This poor performance has lead students spending extra years before they could graduate with a pass degree at best. Alternatively, they could be withdrawn from the University due to the lapse of the given probation period for those who had a CGPA of less than 1.0 in two consecutive academic sessions.

In order to solve the problems of students being withdrawn, spending extra years and being on probation as a result of poor academic performance, there is need to predict and find out what is/are responsible for the poor academic performance from their entry requirement(s).

\subsection{Aim and Objectives of Study}

This study aims to investigate the relationship between the entry requirements into any of the Faculty of Science undergraduate full-time degree programmes in the Kaduna State University and the students' academic performance at the end of the first year of study. The objectives of this study are to:

i. Determine if any of the following entry qualification used for admission, OL results only, UTME scores only or Post-UTME scores (average of OL results and UTME scores) best predict the academic performance of students in the 100 level CGPA examinations;

ii. Investigate the relationship between the students' performance of their entry qualification and the academic performance in the 100 level CGPA examinations.

\subsection{Research Question}

The following research questions directed the study:

1. What is the relationship between OL results, UTME scores and Post-UTME scores (average of OL results \& UTME scores) of students and their first-year CGPA in each of the respective undergraduate degree programmes in the Faculty of Science?

2. How well do OL results, UTME scores and Post-UTME scores of students predict their first-year CGPA in each of the respective undergraduate degree programmes in the Faculty of Science?

3. What is the relationship between OL results, UTME scores and Post-UTME scores of students and their 
first-year CGPA across each academic session, from $2010 / 2011$ to $2014 / 2015$ ?

4. How well do OL results, UTME scores and Post-UTME scores of students predict their first-year CGPA across each academic session, from 2010/2011 to 2014/2015?

\section{Review of Related Literature}

Performance as defined by [7], is an observable or measurable behaviour of a person or an animal in a particular or experimental situation in which the authors further explained that performance measures the behaviours within a specific period. The authors in [8] stated that the concept of academic performance is unavoidable as it "expresses the learning achievement of an individual" at the end of any academic programme of study. It is a yardstick that is used to ascertain the competences of a student from which his abilities could be determined. The authors further explained that academic performance is usually used to determine "how well an individual assimilates, retains, recalls and communicates his knowledge of what is learnt and acquired".

There are a lot of definitions of students' performance based on previous works of literature. Reference [9] stated that students' performance could be obtained by measuring the learning assessment and co-curriculum. However, most of the studies mention graduation being the measure of students' success. Academic performance or sometimes known as an academic achievement is defined by [10] as "Knowledge attained or skill developed in the school subjects, usually designated by test scores or by marks assigned by teachers".

A student's academic performance usually is measured in either examinations or continuous assessment tests, and this is expressed in various ways depending on what the scores should be used for. The numerous ways of reporting academic performance include raw scores, percentages, transformed scores, or even as categorical variables such as Excellent, Merit, Very Good, Pass, First Class, Distinction, A1, B2, C4, F9, and others. Students' academic performance which is a function of many variables, could be classified as a student, home, school, teacher, cultural and legal factors [8]. In Nigeria, students are admitted into universities using their scores in the UTME as well as Post-UTME (PUTME) subject to having at least five OL credit passes in relevant subjects obtained in not more than two examination sittings including the English Language. The underlying assumption made in such selection is that those admitted by satisfying the admission criteria will be successful in the successive academic activities attached to their studies.

Several studies have criticised the use of UTME and PUTME as an imperfect instrument for predicting academic performance of students. Wide disparities have cited between UTME and PUTME scores and the progress/performance of students especially those with exceptionally high UTME scores. However, the following review of literature examined the relationships between UTME and PUTME scores as a predictor for the academic performance of students have revealed contradictions in their findings.

Reference [11], in his study, monitored the performance of science education students admitted through Post UME screening in 2005/2006 academic session. A sample of 214 students records was used for data collection. The author's findings in his study showed that there was a consistent decline in the number of students admitted using the PUTME which cannot do better than UTME in influencing students' academic performance as the outstanding and weak students formed the upper $12.5 \%$ and lower $12.5 \%$ while the remaining $75 \%$ consists of the average students.

The authors in [8] comparatively analysed the academic performance of graduates admitted through UTME and preliminary programmes (Certificate, Basic Studies and School of Science Laboratory Technology [SSLT]) in the University of Port Harcourt. The records of students who graduated in the 2009/2010 and 2010/2011 academic sessions from seven faculties were obtained using the stratified random sampling technique. The authors tested their nine hypotheses using an independent samples t-test and two-way analysis of variance. Their results showed that in all the faculties with the exemption of Agricultural Science and Engineering, the graduates admitted through the preliminary programmes performed significantly better than their counterparts admitted through the UTME. Graduates with the best academic performance from the preliminary programmes were those admitted through the certificate programme.

Reference [1] used the Pearson Product Moment Correlation Coefficient (PPMCC) to predict the academic performance of first-year students in four departments in the University of Abuja from 2008/2009 to 2010/2011 academic sessions using UTME, PUTME and CGPA. Their results revealed that the correlations coefficient between PUTME and CGPA for the four departments were negative/low, positive/low and positive/moderate coefficients. Due to this, the recommendation was that the stakeholders should review the use of UTME and PUTME results for university admissions.

Partial Correlations Coefficient (PCC) was used in addition to PPMCC in [12] to predict the student's final grade in from a sample population of 306 students of Faculty of Health Sciences and Technology at the Enugu Campus of the University of Nigeria that had their final results ready and approved by Senate at the end of 2012. The author's study found that the use UTME score was a very poor predictor of students' final grades and thereby recommended that less emphasis should be placed on UTME scores as a criterion for admission of candidates into universities.

The study by [13] found a significant relationship between students' scores in three examinations, namely: UTME, PUTME and 100-Level Psychology course, Faculty of Agriculture, Federal University of Agriculture, Makurdi, and thus concluded that the UTME has predictive validity for performance in the university.

In the same vein, [14] tested the predictive power of the 
JAMB UTME in predicting students' performance in the university's semester examination by using a regression model. The authors used records of students admitted via the JAMB UTME from a Nigerian private university. Their results suggested that the JAMB UTME had positive but low indices of predictive validity, which varied across the academic sessions from 2005/2006 to 2013/2014 and all programmes of study except for four departments. The article recommended that JAMB should embark on a more realistic review of the content of the UTME to enhance its predictive validity.

In contrast to the studies from the earlier mentioned authors, [15] investigated the relationship between 276 students' performance in the entrance examination and their performance in Mathematics in two selected Colleges of Education (CoE) in Osun and Oyo states each. The sample population consisted of students who were admitted during the 2010/2011 academic sessions but have graduated at the end of the 2012/2013 academic session. The data obtained were semester results in Mathematics during 2010/2011 to 2012/2013 sessions and their grades in Mathematics from any of the public entry examinations known in Nigeria such as UTME, WAEC, NECO, and National Business and Technical Examinations Board (NABTEB). The results indicated no significant relationship between students' performance in the entrance examination and their Mathematics performance at the CoE thereby ascertaining that UTME was the best predictor. The author concluded that the entry qualification or the entrance examination performance could not individually predict Mathematics performance at the CoE.

Furthermore, [16] used the PPMCC analysis to investigate to which extent the scores of UTME and PUTME predicted the academic performance of university undergraduates. A population of 1650 students admitted into the university during the 2011/2012 academic session from Faculties of Arts, Education, Science and Social and Management Science was used to obtain their UTME, PUTME scores along with their GPA for eight semesters. The author concluded from his findings that the use of PUTME is beneficial for selection of candidates for admission and also that candidates who had a high-performance level in the UTME have a positive effect on the academic performance in the university. The author further recommended the need for the PUTME exercise to be strengthened to have a fruitful admission of candidates.

One major shortcoming of virtually all the studies reviewed is their scope in time and spread/coverage. For instance, [12] M.Sc. Dissertation examined the relative strength of UTME and PUTME as academic performance predictor for 306 students admitted in the 2005/2006 and 2006/2007 academic sessions and whose results were ready and approved by the University Senate no later than 2012. The study in [11] monitored the performance of only 214 Science Education students admitted through
PUTME screening from 2005/2006 to their third year of studies (2007/2008), in four departments - Biology, Chemistry, Mathematics and Physics in Delta State University, Abraka, found no significant correlations in the CGPA scores of students admitted through the two sets of criteria.

\section{Methodology}

This study aimed to investigate which of the University's entry requirements used for the admission process best predicts the academic performance of students in the 100 level CGPA examinations. This section discussed in detail the methodology employed such as research design, sample of study, instruments used, the procedure for the collection of data and data analysis.

\subsection{Research Design}

This study adopted the descriptive, also known as ex-post facto, research design that is defined by [17] as "a methodological approach for eliciting possible or probable antecedents of events that have occurred already and which cannot be subjected to the direct, rigorous manipulation and control". He explained that there are two types of ex-post facto research designs namely the correlational and the casual comparative. The design adopted in the study is the correlational ex-post facto, which is used to measure the degree of association between two or more variables or sets of scores. The correlational design is also sub-divided into explanatory and predictive research designs.

The Predictive Correlational Ex-Post Facto design was identified to be the most appropriate for the study since the results (CGPA, UTME and OL) of students in the Faculty of Science were used in reaching conclusions about the whole prediction of academic performance.

\subsection{Sample of the Study}

The Faculty of Science consists of nine undergraduate B. Sc. Full-time degree programmes: Biochemistry, Biological Sciences, Chemistry, Computer Science, Geography, Industrial Chemistry, Microbiology, Mathematical Sciences, and Physics.

The population of the study was limited to consist of all students admitted into three Faculty of Science undergraduate degree programmes of Kaduna State University for five academic sessions from $2010 / 2011$ to $2014 / 2015$ using the OL, UTME and CGPA results. This limitation is due to the non-availability of CGPA results of the other undergraduate degree programmes at the time required. The size of the target population is 3255 students out of which 943 students were purposively sampled from Mathematics, Computer Science, and Physics degree programmes. The sample distribution is as shown in Table 1. 
Table 1. Distribution of Students Admitted into the Faculty of Science from 2010/2011 to 2014/2015 Academic Sessions.

\begin{tabular}{|c|c|c|c|c|c|c|}
\hline \multirow{2}{*}{ PROGRAMMES } & \multicolumn{5}{|c|}{ ACADEMIC SESSIONS } & \multirow{2}{*}{ TOTAL } \\
\hline & 2010/2011 & 2011/2012 & $2012 / 2013$ & 2013/2014 & $2014 / 2015$ & \\
\hline Biochemistry & 76 & 62 & 75 & 79 & 86 & 378 \\
\hline Biological Sciences & 94 & 119 & 78 & 69 & 93 & 453 \\
\hline Chemistry & 78 & 81 & 79 & 85 & 93 & 416 \\
\hline Computer Science & 73 & 70 & 94 & 72 & 88 & 397 \\
\hline Geography & 69 & 75 & 85 & 70 & 90 & 389 \\
\hline Industrial Chemistry & 25 & 30 & 28 & 45 & 57 & 185 \\
\hline Microbiology & 76 & 60 & 132 & 110 & 113 & 491 \\
\hline Mathematics & 77 & 56 & 65 & 54 & 47 & 299 \\
\hline Physics & 65 & 37 & 55 & 47 & 43 & 247 \\
\hline TOTAL & 633 & 590 & 691 & 631 & 710 & 3255 \\
\hline$\%$ TOTAL & 19.5 & 18.1 & 21.2 & 19.4 & 21.8 & 100.0 \\
\hline
\end{tabular}

Source: Field Survey (2018).

Out of the total sample of 3,255 students admitted between $2010 / 2011$ to $2014 / 2015$ academic sessions, the programme with the highest sample size is Microbiology with 491 (15.1\%), followed by Biological Sciences (13.9\%) whereas the programme with the least sample size is Industrial Chemistry $(5.7 \%)$. The session with the largest sample size was 2014/2015 with 710 (21.8\%) students.

\subsection{Instrument}

The instrument used to derive the data for this study were: the JAMB UTME scores from 2010 to 2014 and OL grades in the five relevant subjects which were the pre-admission criteria and first-year CGPA results obtained from the semester examinations from $2010 / 2011$ to $2014 / 2015$ academic sessions. The UTME was wholly multiple-choice objective questions conducted via Computer-Based Tests (CBTs) by JAMB. The semester examinations were mostly essay type questions.

\subsection{Procedure for Data Collection}

The data used in the study are the OL grades, and JAMB UTME scores obtained from the University's central database, and the academic standing of first-year CGPA results collected from the various departmental examination officers (DEOs) with the approval from the Dean of the Faculty of Science. However, the OL results obtained from the database was for students admitted during 2010/2011 to 2014/2015 academic sessions.

\subsection{Method for Data Analysis}

The stanine grades in the OL results obtained at either NECO or WAEC were collected and coded as shown in Table 2. Stanine (STAndard NINE) was defined as "a nine-point scoring system with a mean of five and a standard deviation of two" [18] and is used in education to compare student performance for each subject. The total score for five relevant subjects in OL is then computed and coded together with the UTME and PUTME scores which are as shown in Table 3. The coding for the CGPA is also shown in Table 4. The collected data once coded was finally analysed with the aid of the most widely used and robust data analysis software, SPSS developed by International Business Machines (IBM) since 2009. SPSS is an acronym for Statistical Package for Social Sciences, but now it can also be referred to as Statistical Product and Service Solutions. It was used in this research study.

Table 2. Ordinary Level Stanine Grades and their Weights Used.

\begin{tabular}{llllll}
\hline STANINE GRADE & A1 & B2/B3 & C4/C5/C6 & D7/D8 & F9 \\
\hline WEIGHTS & 4 & 3 & 2 & 1 & 0 \\
\hline
\end{tabular}

Source: Field Survey (2018).

Table 3. Coding Scale used for OL, UTME and PUTME.

\begin{tabular}{|c|c|c|c|c|c|c|}
\hline WEIGHTS & $\mathbf{0}$ & 1 & 2 & 3 & 4 & 5 \\
\hline $\mathrm{OL}$ & $36-44$ & $45-52$ & $53-60$ & $61-68$ & $69-76$ & $77-84$ \\
\hline UME & $180-198$ & $199-216$ & $217-234$ & $235-252$ & $253-270$ & $271-288$ \\
\hline PUTME & $165.6-187.5$ & $187.6-209.5$ & $209.6-231.5$ & $231.6-253.5$ & $253.6-275.5$ & $275.6-297.5$ \\
\hline
\end{tabular}

Source: Field Survey (2018).

Table 4. Nigerian Universities Class of Degrees, CGPA and Coding Scale Used.

\begin{tabular}{|c|c|c|c|c|c|c|}
\hline CGPA & $0.0-0.99$ & $1.00-1.49$ & $1.50-2.39$ & $2.40-3.49$ & $3.50-4.49$ & $4.50-5.00$ \\
\hline CLASS & Fail & Pass & $3^{\text {rd }}$ Class & $2^{\text {nd }}$ Class Lower & $2^{\text {nd }}$ Class Upper & $1^{\text {st }}$ Class \\
\hline WEIGHTS & 0 & 1 & 2 & 3 & 4 & 5 \\
\hline
\end{tabular}

Source: Field Survey (2018).

Since the focus of the study is to determine the predictive validity of OL results and CGPA scores (OL-CGPA), UTME and CGPA scores (UTME-CGPA), and PUTME and CGPA scores (PUTME-CGPA), the statistics employed on the extracted data were Multinominal Logistic Regression (MLR) and Pearson Product Moment Correlation (PPMC) 
coefficient. The data were regrouped and analysed by academic session and programme of study.

PPMC is used to determine the degree of relationship between two sets of variables and compute the strength of association between the variables [19]. There are three types of linear relationship that may exist between these two variables namely positive linear correlation, negative linear correlation and no correlation.

MLR often called 'multinomial regression', is used to "predict categorical placement in or the probability of category membership on a dependent (criterion) variable based on multiple independent (predictor) variables" [20]. In other words, MLR is used to predict a nominal dependent variable given one or more independent variables. MLR can have interactions between nominal and continuous independent variables to predict the dependent variable.

\section{Results and Discussion}

The results of the data analysis are presented in tables according to the research questions that guided the study in this section.

\subsection{Research Question 1}

What is the relationship between OL results, UTME scores and Post-UTME scores (average of OL results \& UTME scores) of students and their first-year CGPA in each of the respective undergraduate degree programmes in the Faculty of Science?

Table 5 shows the summary of correlations coefficient between OL results and CGPA scores (OL-CGPA), UTME and CGPA scores (UTME-CGPA) and PUTME and CGPA scores (PUTME-CGPA) aimed at all the academic sessions for Computer Science, Mathematics and Physics degree programmes.

Table 5. Summary of Correlations between OL, UTME and PUTME against CGPA for the undergraduate degree programmes.

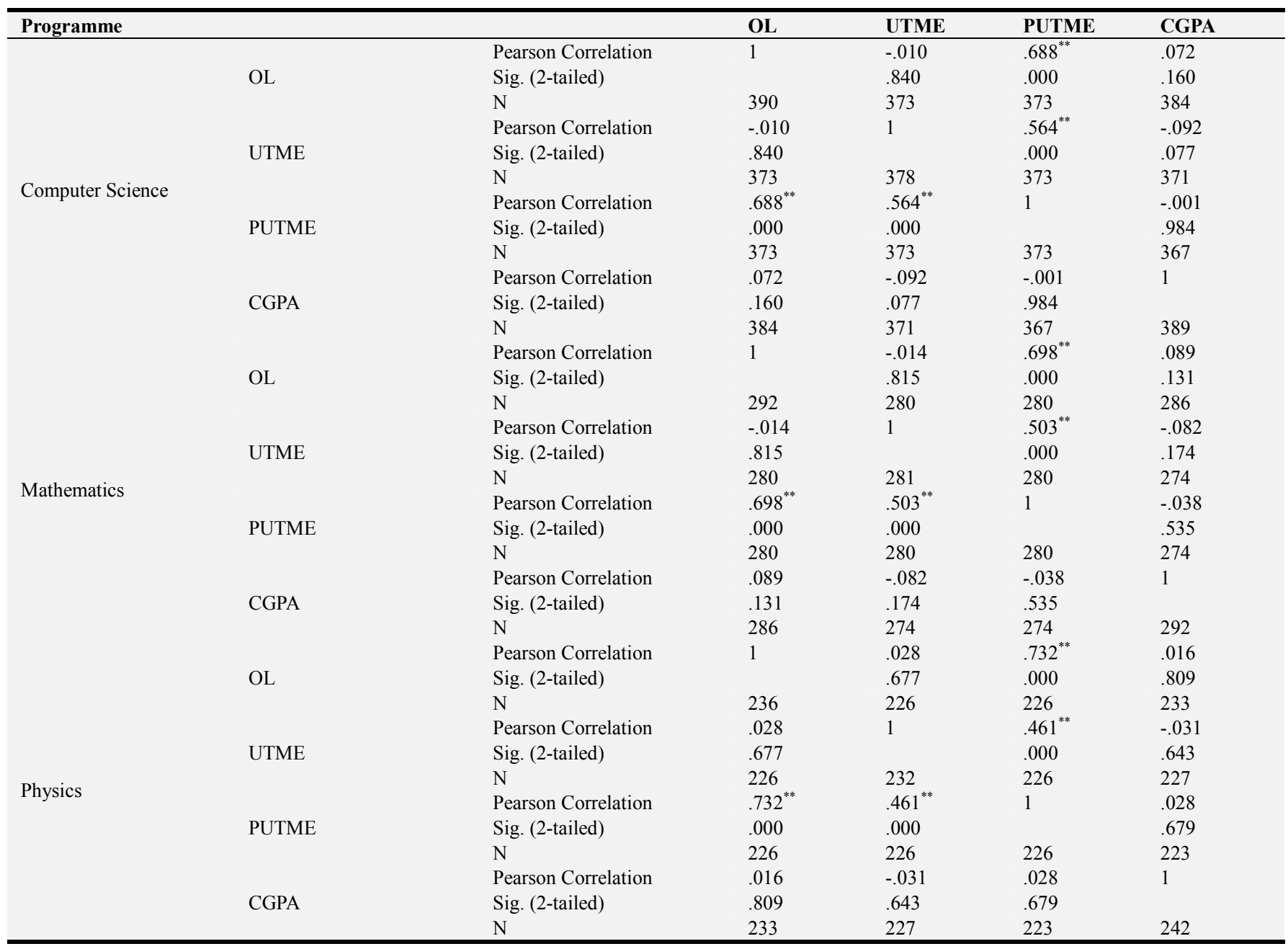

** Correlation is significant at the 0.01 level (2-tailed).

Source: SPSS (2018).

The Pearson Correlation analysis was carried out to find out if there exists a strong positive correlation between $\mathrm{OL}$ and CGPA, UTME and CGPA and PUTME and CGPA. For the Computer Science programme, as shown in Table 5, the correlation coefficient indicated a low negative correlation in UTME-CGPA (-0.092) and PUTME-CGPA (-0.001) and a 
low positive correlation for OL-CGPA (0.072). Similarly, there exists a low negative correlation in UTME-CGPA (0.082) and PUTME-CGPA (-0.038) and a low positive relationship in OL-CGPA (0.089) for the Mathematics programme. In the Physics programme, there exists a low positive relationship in OL-CGPA (0.016), PUTME-CGPA (0.028) and a low negative relationship in UTME-CGPA (0.031). The indication shows that the nine correlation coefficients for this research question are very low out of which five have a low negative relationship.

\subsection{Research Question 2}

How well do OL results, UTME scores and Post-UTME scores of students predict their first-year CGPA in each of the respective undergraduate degree programmes in the Faculty of Science?

Table 6 is the likelihood ratio test results for the Computer Science, Mathematics and Physics degree programmes. Likelihood Ratio Tests is a statistical test of the goodness-offit between two models.

Table 6. Likelihood Ratio Test Results for Degree Programmes.

\begin{tabular}{|c|c|c|c|c|c|}
\hline \multirow{2}{*}{ Programme } & & \multirow{2}{*}{$\begin{array}{l}\text { Model Fitting Criteria } \\
\text {-2 Log Likelihood }\end{array}$} & \multicolumn{3}{|c|}{ Likelihood Ratio Tests } \\
\hline & & & Chi-Square & df & Sig. \\
\hline \multirow{2}{*}{ Computer Science } & Intercept Only & 341.946 & & & \\
\hline & Final & 323.223 & 18.723 & 15 & .227 \\
\hline \multirow{2}{*}{ Mathematics } & Intercept Only & 285.744 & & & \\
\hline & Final & 268.083 & 17.661 & 15 & .281 \\
\hline \multirow{2}{*}{ Physics } & Intercept Only & 199.772 & & & \\
\hline & Final & 187.371 & 12.401 & 12 & .414 \\
\hline
\end{tabular}

Source: SPSS (2018).

In Table 6, the likelihood ratio Chi-Square of 18.723 , 17.661 and 12.401 for Computer Science, Mathematics and Physics programmes with a significant value of $0.227,0.281$ and 0.414 tells us that the model as a whole does not predict the dependent variable, i.e., CGPA.

Table 7 shows the results of the Parameter estimates, which is also called coefficients, for the Multinomial Logistic
Regression (MLR) for each degree programme. A Multinomial Logistic Regression (MLR) was performed to model the relationship between the predictors and membership in the six groups, i.e., CGPA categories (Fail, Pass, $3^{\text {rd }}$ Class, $2^{\text {nd }}$ Class Lower, $2^{\text {nd }}$ Class Upper and $1^{\text {st }}$ Class) for each degree programme.

Table 7. Parameter Estimates for the Multinomial Logistic Regression for Degree Programmes.

\begin{tabular}{|c|c|c|c|c|c|c|c|c|}
\hline Programme & & & B & Std. Error & Wald & df & Sig. & $\operatorname{Exp}(B)$ \\
\hline \multirow{16}{*}{$\mathrm{CSC}$} & \multirow{3}{*}{ 1.00-1.49 (Pass) } & Intercept & .809 & .911 & .789 & 1 & .375 & \\
\hline & & $\mathrm{OL}$ & .429 & .539 & .634 & 1 & .426 & 1.536 \\
\hline & & UTME & .001 & .356 & .000 & 1 & .997 & 1.001 \\
\hline & \multirow{3}{*}{$1.50-2.39$ (3rd Class) } & Intercept & 2.377 & .794 & 8.963 & 1 & .003 & \\
\hline & & $\mathrm{OL}$ & .080 & .473 & .028 & 1 & .866 & 1.083 \\
\hline & & UTME & -.246 & .311 & .625 & 1 & .429 & .782 \\
\hline & \multirow{4}{*}{ 2.40-3.49 (2.2 Class) } & Intercept & 1.646 & .791 & 4.333 & 1 & .037 & \\
\hline & & $\mathrm{OL}$ & .434 & .466 & .865 & 1 & .352 & 1.543 \\
\hline & & UTME & -.278 & .308 & .812 & 1 & .368 & .758 \\
\hline & & PUTME & -.335 & .631 & .283 & 1 & .595 & .715 \\
\hline & \multirow{4}{*}{ 3.50-4.49 (2.1 Class) } & Intercept & 1.357 & .870 & 2.436 & 1 & .119 & \\
\hline & & $\mathrm{OL}$ & .240 & .511 & .220 & 1 & .639 & 1.271 \\
\hline & & UTME & -.445 & .345 & 1.660 & 1 & .198 & .641 \\
\hline & & PUTME & -.264 & .694 & .145 & 1 & .703 & .768 \\
\hline & \multirow{3}{*}{$4.50-5.00$ (1st Class) } & $\mathrm{OL}$ & .758 & .675 & 1.260 & 1 & .262 & 2.134 \\
\hline & & UTME & .182 & .450 & .163 & 1 & .686 & 1.199 \\
\hline \multirow{13}{*}{ MTH } & & PUTME & -.518 & .920 & .318 & 1 & .573 & .595 \\
\hline & \multirow{4}{*}{$1.00-1.49$ (Pass) } & Intercept & .422 & .774 & .297 & 1 & .586 & \\
\hline & & $\mathrm{OL}$ & .225 & .483 & .218 & 1 & .641 & 1.253 \\
\hline & & UTME & -.049 & .311 & .024 & 1 & .876 & .953 \\
\hline & & PUTME & -.336 & .610 & .303 & 1 & .582 & .715 \\
\hline & \multirow{4}{*}{ 1.50-2.39 (3rd Class) } & Intercept & -.109 & .729 & .022 & 1 & .881 & \\
\hline & & $\mathrm{OL}$ & .487 & .435 & 1.249 & 1 & .264 & 1.627 \\
\hline & & UTME & -.127 & .282 & .202 & 1 & .653 & .881 \\
\hline & & PUTME & -.133 & .557 & .058 & 1 & .810 & .875 \\
\hline & \multirow{4}{*}{$2.40-3.49$ (2.2 Class) } & Intercept & .623 & .709 & .770 & 1 & .380 & \\
\hline & & $\mathrm{OL}$ & .682 & .432 & 2.490 & 1 & .115 & 1.979 \\
\hline & & UTME & -.208 & .287 & .523 & 1 & .470 & .813 \\
\hline & & PUTME & -.627 & .550 & 1.297 & 1 & .255 & .534 \\
\hline
\end{tabular}




\begin{tabular}{|c|c|c|c|c|c|c|c|c|}
\hline Programme & & & B & Std. Error & Wald & df & Sig. & $\operatorname{Exp}(B)$ \\
\hline \multirow{24}{*}{ PHY } & \multirow{4}{*}{$3.50-4.49$ (2.1 Class) } & Intercept & .373 & .762 & .240 & 1 & .625 & \\
\hline & & $\mathrm{OL}$ & .398 & .472 & .709 & 1 & .400 & 1.488 \\
\hline & & UTME & .051 & .304 & .028 & 1 & .867 & 1.052 \\
\hline & & PUTME & -.499 & .597 & .696 & 1 & .404 & .607 \\
\hline & \multirow{4}{*}{$4.50-5.00$ (1st Class) } & Intercept & -4.635 & 2.231 & 4.315 & 1 & .038 & \\
\hline & & $\mathrm{OL}$ & 2.901 & 1.387 & 4.376 & 1 & .036 & 18.194 \\
\hline & & UTME & .567 & .769 & .543 & 1 & .461 & 1.763 \\
\hline & & PUTME & -2.551 & 1.566 & 2.651 & 1 & .103 & .078 \\
\hline & \multirow{4}{*}{ 1.00-1.49 (Pass) } & Intercept & .514 & 1.262 & .166 & 1 & .684 & \\
\hline & & $\mathrm{OL}$ & .861 & .702 & 1.508 & 1 & .220 & 2.367 \\
\hline & & UTME & -.593 & .491 & 1.459 & 1 & .227 & .553 \\
\hline & & PUTME & -.534 & 1.009 & .280 & 1 & .597 & .586 \\
\hline & \multirow{4}{*}{$1.50-2.39$ (3rd Class) } & Intercept & .988 & 1.163 & .721 & 1 & .396 & \\
\hline & & $\mathrm{OL}$ & .641 & .656 & .956 & 1 & .328 & 1.899 \\
\hline & & UTME & -.531 & .443 & 1.440 & 1 & .230 & .588 \\
\hline & & PUTME & -.167 & .939 & .032 & 1 & .859 & .846 \\
\hline & \multirow{4}{*}{$2.40-3.49$ (2.2 Class) } & Intercept & 1.197 & 1.162 & 1.061 & 1 & .303 & \\
\hline & & $\mathrm{OL}$ & .630 & .657 & .918 & 1 & .338 & 1.877 \\
\hline & & UTME & -.404 & .442 & .833 & 1 & .361 & .668 \\
\hline & & PUTME & -.305 & .940 & .105 & 1 & .745 & .737 \\
\hline & \multirow{4}{*}{$3.50-4.49$ (2.1 Class) } & Intercept & -.518 & 1.349 & .147 & 1 & .701 & \\
\hline & & $\mathrm{OL}$ & -.271 & .759 & .128 & 1 & .721 & .762 \\
\hline & & UTME & -.903 & .515 & 3.067 & 1 & .080 & .405 \\
\hline & & PUTME & 1.098 & 1.088 & 1.018 & 1 & .313 & 2.997 \\
\hline
\end{tabular}

Source: SPSS (2018).

The traditional 0.05 criterion of statistical significance was employed for all tests in Table 7. Each of the five equations for every degree programme in Table 7 includes the intercept and the slope for the predictors. For Computer Science, Mathematics and Physics programmes, the first equation intercept is the $\log$ of the ratio of the likelihood of a student having a 'pass' degree to the likelihood of that student having a 'Fail' degree. Among the classification of degrees, each of the five subgroups for each programme, that is Pass, $3^{\text {rd }}$ Class, $2^{\text {nd }}$ Class Lower, $2^{\text {nd }}$ Class Upper and $1^{\text {st }}$ Class, are contrasted with the baseline group of 'fail' degree.

For the Computer Science programme, the slopes (B) of OL in all the CGPA categories are positive. These showed that the relative strengths of their OL result performance on the CGPA categories of 'Pass', ' $3{ }^{\text {rd }}$ Class', ' 2 nd $C$ Class Lower', ' $2{ }^{\text {nd }}$ Class Upper' and ' 1 st Class' are higher than those with a CGPA category of 'Fail'. Besides, the slopes (B) of UTME in the CGPA categories of 'Pass' and ' $1{ }^{\text {st }}$ Class' are positive while the rest are negative. This result shows that the relative strength of UTME on the former is higher than those with a CGPA category of 'Fail' and otherwise for the latter. Finally, the slope (B) of PUTME in all the CGPA categories is negative, which shows that the relative strength of those with a CGPA category of 'Fail' is higher than the other categories. However, the relative strength of OL, UTME and PUTME on CGPA performance of Computer Science students is not statistically significant.

For Mathematics and Physics students the relative strength of OL, UTME and PUTME on CGPA performance are statistically insignificant except for the slope (B) of OL in the CGPA category of ' $1^{\text {st }}$ Class' for Mathematics students, which statistically significant.

\subsection{Research Question 3}

What is the relationship between OL results, UTME scores and Post-UTME scores of students and their firstyear CGPA across the academic session, 2010/2011 to $2014 / 2015$ ?

Table 8 shows the summary of correlations coefficient between OL-CGPA, UTME-CGPA and PUTME-CGPA aimed at all the degree programmes for the academic sessions ranging from 2010/2011 to 2014/2015.

Table 8. Summary of Correlations between OL, UTME and PUTME against CGPA for the 5 Academic Sessions (2010-2014).

\begin{tabular}{|c|c|c|c|c|c|}
\hline Academic Year & & OL & UTME & PUTME & CGPA \\
\hline \multirow{9}{*}{2010} & Pearson Correlation & 1 & .094 & $.699^{* *}$ & $.198^{* *}$ \\
\hline & Sig. (2-tailed) & & .182 & .000 & .004 \\
\hline & $\mathrm{N}$ & 211 & 205 & 205 & 209 \\
\hline & Sig. (2-tailed) & .182 & & .000 & .007 \\
\hline & $\mathrm{N}$ & 205 & 205 & 205 & 203 \\
\hline & Pearson Correlation & $.699^{* *}$ & $.613^{* *}$ & 1 & $.232^{* *}$ \\
\hline & $\mathrm{N}$ & 205 & 205 & 205 & 203 \\
\hline & Pearson Correlation & $.198^{* *}$ & $.189^{* *}$ & $.232^{* *}$ & 1 \\
\hline & Sig. (2-tailed) & .004 & .007 & .001 & \\
\hline
\end{tabular}




\begin{tabular}{|c|c|c|c|c|c|c|}
\hline \multicolumn{3}{|c|}{ Academic Year } & \multirow{2}{*}{$\begin{array}{l}\text { OL } \\
209\end{array}$} & \multirow{2}{*}{$\begin{array}{l}\text { UTME } \\
203\end{array}$} & \multirow{2}{*}{$\begin{array}{l}\text { PUTME } \\
203\end{array}$} & \multirow{2}{*}{$\begin{array}{l}\text { CGPA } \\
213\end{array}$} \\
\hline \multirow{13}{*}{2011} & \multirow{4}{*}{ OL } & $\mathrm{N}$ & & & & \\
\hline & & Pearson Correlation & 1 & -.059 & $.642^{* *}$ & -.114 \\
\hline & & Sig. (2-tailed) & & .463 & .000 & .152 \\
\hline & & $\mathrm{N}$ & 161 & 157 & 157 & 159 \\
\hline & \multirow{3}{*}{ UTME } & Pearson Correlation & -.059 & 1 & $.546^{* *}$ & .114 \\
\hline & & Sig. (2-tailed) & .463 & & .000 & .157 \\
\hline & & $\mathrm{N}$ & 157 & 157 & 157 & 155 \\
\hline & \multirow{3}{*}{ PUTME } & Pearson Correlation & $.642^{* *}$ & $.546^{* *}$ & 1 & -.043 \\
\hline & & Sig. (2-tailed) & .000 & .000 & & .595 \\
\hline & & $\mathrm{N}$ & 157 & 157 & 157 & 155 \\
\hline & \multirow{3}{*}{ CGPA } & Pearson Correlation & -.114 & .114 & -.043 & 1 \\
\hline & & Sig. (2-tailed) & .152 & .157 & .595 & \\
\hline & & $\mathrm{N}$ & 159 & 155 & 155 & 161 \\
\hline \multirow{12}{*}{2012} & \multirow{3}{*}{$\mathrm{OL}$} & Pearson Correlation & 1 & -.007 & $.702^{* *}$ & .111 \\
\hline & & Sig. (2-tailed) & & .920 & .000 & .116 \\
\hline & & $\mathrm{N}$ & 207 & 202 & 202 & 203 \\
\hline & \multirow{3}{*}{ UTME } & Pearson Correlation & -.007 & 1 & $.553^{* *}$ & $-.363^{* *}$ \\
\hline & & Sig. (2-tailed) & .920 & & .000 & .000 \\
\hline & & $\mathrm{N}$ & 202 & 204 & 202 & 198 \\
\hline & \multirow{3}{*}{ PUTME } & Pearson Correlation & $.702^{* *}$ & $.553^{* *}$ & 1 & -.123 \\
\hline & & Sig. (2-tailed) & .000 & .000 & & .085 \\
\hline & & $\mathrm{N}$ & 202 & 202 & 202 & 198 \\
\hline & \multirow{4}{*}{ CGPA } & Pearson Correlation & .111 & $-.363^{* *}$ & -.123 & 1 \\
\hline & & Sig. (2-tailed) & .116 & .000 & .085 & \\
\hline & & $\mathrm{N}$ & 203 & 198 & 198 & 207 \\
\hline \multirow{11}{*}{2013} & & Pearson Correlation & 1 & -.031 & $.734^{* *}$ & .061 \\
\hline & \multirow[t]{2}{*}{$\mathrm{OL}$} & Sig. (2-tailed) & & .710 & .000 & .432 \\
\hline & & $\mathrm{N}$ & 171 & 147 & 147 & 168 \\
\hline & \multirow{3}{*}{ UTME } & Pearson Correlation & -.031 & 1 & $.435^{* *}$ & .056 \\
\hline & & Sig. (2-tailed) & .710 & & .000 & .502 \\
\hline & & $\mathrm{N}$ & 147 & 147 & 147 & 144 \\
\hline & \multirow{3}{*}{ PUTME } & Pearson Correlation & $.734^{* *}$ & $.435^{* *}$ & 1 & .038 \\
\hline & & Sig. (2-tailed) & .000 & .000 & & .649 \\
\hline & & $\mathrm{N}$ & 147 & 147 & 147 & 144 \\
\hline & \multirow{3}{*}{ CGPA } & Pearson Correlation & .061 & .056 & .038 & 1 \\
\hline & & Sig. (2-tailed) & .432 & .502 & .649 & \\
\hline \multirow{13}{*}{2014} & & $\mathrm{~N}$ & 168 & 144 & 144 & 170 \\
\hline & & Pearson Correlation & 1 & .106 & $.805^{* *}$ & -.071 \\
\hline & OL & Sig. (2-tailed) & & .172 & .000 & .367 \\
\hline & & $\mathrm{N}$ & 168 & 168 & 168 & 164 \\
\hline & & Pearson Correlation & .106 & 1 & $.346^{* *}$ & -.090 \\
\hline & UTME & Sig. (2-tailed) & .172 & & .000 & .238 \\
\hline & & $\mathrm{N}$ & 168 & 178 & 168 & 172 \\
\hline & & Pearson Correlation & $.805^{* *}$ & $.346^{* *}$ & 1 & -.040 \\
\hline & PUTME & Sig. (2-tailed) & .000 & .000 & & .615 \\
\hline & & $\mathrm{N}$ & 168 & 168 & 168 & 164 \\
\hline & & Pearson Correlation & -.071 & -.090 & -.040 & 1 \\
\hline & CGPA & Sig. (2-tailed) & .367 & .238 & .615 & \\
\hline & & $\mathrm{N}$ & 164 & 172 & 164 & 172 \\
\hline
\end{tabular}

**. Correlation is significant at the 0.01 level (2-tailed).

Source: SPSS (2018).

PPMC was used to analyse the data for this research question. The summary of Table 8 shows the correlations of OL and CGPA scores, UTME and CGPA scores and PUTME and CGPA scores for all the programmes used for the analysis. In the 2010/2011 academic session, the correlation coefficient indicated a low positive correlation in OL-CGPA (0.198), UTME-CGPA (0.189), and PUTMECGPA (0.232). In 2011/2012, OL-CGPA (-0.114) and PUTME-CGPA (-0.043) display low negative correlation while UTME-CGPA (0.114) has low positive correlation. In 2012/2013, UTME-CGPA (-0.363) and PUTME-CGPA $(-0.123)$ have low negative relationship whereas OL-
CGPA (0.111) has a low positive relationship. In 2013/2014, there exist a low positive association for OLCGPA (0.061), UTME-CGPA (0.056), and PUTME-CGPA (0.038). The OL-CGPA (-0.071), UTME-CGPA (-0.090), and PUTME-CGPA $(-0.040)$ in the 2014/2015 session signifies a low negative correlation. However, the entire results revealed that all the 15 correlation coefficients are very low, with seven of the result showing a low negative correlation relationship.

\subsection{Research Question 4}

How well do OL results, UTME scores and Post-UTME 
scores of students predict their first-year CGPA across the academic session, $2010 / 2011$ to $2014 / 2015$ ?
Table 9 is the likelihood ratio test results for all academic sessions ranging from $2010 / 2011$ to $2014 / 2015$.

Table 9. Likelihood Ratio Test Results for all Academic Sessions.

\begin{tabular}{|c|c|c|c|c|c|}
\hline \multirow{2}{*}{\multicolumn{2}{|c|}{ Year of Entry }} & \multirow{2}{*}{$\begin{array}{l}\text { Model Fitting Criteria } \\
-2 \text { Log Likelihood }\end{array}$} & \multicolumn{3}{|c|}{ Likelihood Ratio Tests } \\
\hline & & & Chi-Square & df & Sig. \\
\hline \multirow{2}{*}{2010} & Intercept Only & 271.947 & & & \\
\hline & Final & 234.502 & 37.446 & 15 & .001 \\
\hline \multirow{2}{*}{2011} & Intercept Only & 173.390 & & & \\
\hline & Final & 153.451 & 19.938 & 15 & .174 \\
\hline \multirow{2}{*}{2012} & Intercept Only & 268.043 & & & \\
\hline & Final & 221.902 & 46.141 & 15 & .000 \\
\hline 2013 & Final & 143.836 & 14.349 & 15 & .499 \\
\hline \multirow{2}{*}{2014} & Intercept Only & 167.033 & & & \\
\hline & Final & 155.866 & 11.167 & 15 & .741 \\
\hline
\end{tabular}

Source: SPSS (2018).

As shown in the Likelihood Ratio Test results in Table 9, the likelihood ratio Chi-Square of 37.446, 19.938, 46.141, 14.349 and 11.167 for $2010 / 2011,2011 / 2012,2012 / 2013$, $2013 / 2014$ and 2014/2015 academic sessions which has the following as significant values of $0.001,0.174, .000,0.499$ and 0.741 tells us that the model for students admitted during the 2010/2011 and 2012/2013 academic sessions predicts the CGPA, which is the dependent variable while the other academic sessions does not.

Table 10, on the other hand, shows the results of the Parameter estimates for the MLR for each academic session. A Multinomial Logistic Regression (MLR) was performed to model the relationship between the predictors and membership in the CGPA categories for each academic session.

Table 10. Parameter Estimates for the Multinomial Logistic Regression for Academic Sessions.

\begin{tabular}{|c|c|c|c|c|c|c|c|c|}
\hline \multicolumn{3}{|c|}{ Year of Entry } & \multirow{2}{*}{$\begin{array}{l}\text { B } \\
-.236\end{array}$} & \multirow{2}{*}{$\begin{array}{l}\text { Std. Error } \\
1.017\end{array}$} & \multirow{2}{*}{$\begin{array}{l}\text { Wald } \\
.054\end{array}$} & \multirow{2}{*}{$\begin{array}{l}\text { df } \\
1\end{array}$} & \multirow{2}{*}{$\begin{array}{l}\text { Sig. } \\
.817\end{array}$} & \multirow[t]{2}{*}{$\operatorname{Exp}(B)$} \\
\hline \multirow{20}{*}{2010} & \multirow{4}{*}{$1.00-1.49$ (Pass) } & Intercept & & & & & & \\
\hline & & $\mathrm{OL}$ & .955 & .650 & 2.161 & 1 & .142 & 2.600 \\
\hline & & UTME & .003 & .367 & .000 & 1 & .994 & 1.003 \\
\hline & & PUTME & -.576 & .835 & .477 & 1 & .490 & .562 \\
\hline & \multirow{4}{*}{ 1.50-2.39 (3rd Class) } & Intercept & -.725 & 1.008 & .517 & 1 & .472 & \\
\hline & & $\mathrm{OL}$ & .975 & .625 & 2.438 & 1 & .118 & 2.651 \\
\hline & & UTME & -.589 & .362 & 2.650 & 1 & .104 & .555 \\
\hline & & PUTME & .009 & .810 & .000 & 1 & .991 & 1.009 \\
\hline & \multirow{4}{*}{ 2.40-3.49 (2.2 Class) } & Intercept & -.594 & .983 & .365 & 1 & .546 & \\
\hline & & $\mathrm{OL}$ & .889 & .628 & 2.007 & 1 & .157 & 2.433 \\
\hline & & UTME & .078 & .352 & .048 & 1 & .826 & 1.081 \\
\hline & & PUTME & -.278 & .807 & .119 & 1 & .730 & .757 \\
\hline & \multirow{4}{*}{ 3.50-4.49 (2.1 Class) } & Intercept & -2.288 & 1.144 & 3.998 & 1 & .046 & \\
\hline & & $\mathrm{OL}$ & 1.526 & .699 & 4.759 & 1 & .029 & 4.598 \\
\hline & & UTME & .413 & .413 & 1.002 & 1 & .317 & 1.511 \\
\hline & & PUTME & -.745 & .917 & .659 & 1 & .417 & .475 \\
\hline & \multirow{4}{*}{ 4.50-5.00 (1 st Class) } & Intercept & -5.292 & 1.745 & 9.193 & 1 & .002 & \\
\hline & & $\mathrm{OL}$ & 1.307 & 1.020 & 1.643 & 1 & .200 & 3.695 \\
\hline & & UTME & .799 & .680 & 1.378 & 1 & .240 & 2.222 \\
\hline & & PUTME & -.210 & 1.371 & .024 & 1 & .878 & .810 \\
\hline \multirow{16}{*}{2011} & \multirow{4}{*}{$1.00-1.49$ (Pass) } & Intercept & .542 & 1.381 & .154 & 1 & .695 & \\
\hline & & $\mathrm{OL}$ & .829 & .762 & 1.184 & 1 & .277 & 2.290 \\
\hline & & UTME & -.191 & .558 & .117 & 1 & .732 & .826 \\
\hline & & PUTME & -.909 & 1.049 & .750 & 1 & .387 & .403 \\
\hline & \multirow{5}{*}{ 1.50-2.39 (3rd Class) } & Intercept & 3.421 & 1.229 & 7.742 & 1 & .005 & \\
\hline & & $\mathrm{OL}$ & .363 & .684 & .282 & 1 & .595 & 1.438 \\
\hline & & UTME & .042 & .474 & .008 & 1 & .929 & 1.043 \\
\hline & & PUTME & -1.332 & .943 & 1.993 & 1 & .158 & .264 \\
\hline & & Intercept & 2.386 & 1.214 & 3.865 & 1 & .049 & \\
\hline & \multirow{3}{*}{ 2.40-3.49 (2.2 Class) } & $\mathrm{OL}$ & .907 & .686 & 1.752 & 1 & .186 & 2.478 \\
\hline & & UTME & .560 & .463 & 1.463 & 1 & .226 & 1.750 \\
\hline & & PUTME & -1.684 & .931 & 3.269 & 1 & .071 & .186 \\
\hline & \multirow{4}{*}{$3.50-4.49$ (2.1 Class) } & Intercept & 1.315 & 1.384 & .903 & 1 & .342 & \\
\hline & & $\mathrm{OL}$ & -.042 & .816 & .003 & 1 & .959 & .959 \\
\hline & & UTME & .380 & .527 & .521 & 1 & .471 & 1.463 \\
\hline & & PUTME & -.561 & 1.082 & .269 & 1 & .604 & .571 \\
\hline
\end{tabular}




\begin{tabular}{|c|c|c|c|c|c|c|c|c|}
\hline \multicolumn{3}{|c|}{ Year of Entry } & \multirow{2}{*}{$\begin{array}{l}\text { B } \\
1.094\end{array}$} & \multirow{2}{*}{$\begin{array}{l}\text { Std. Error } \\
3.123\end{array}$} & \multirow{2}{*}{$\begin{array}{l}\text { Wald } \\
.123\end{array}$} & \multirow{2}{*}{$\begin{array}{l}\text { df } \\
1\end{array}$} & \multirow{2}{*}{$\begin{array}{l}\text { Sig. } \\
.726\end{array}$} & \multirow[t]{2}{*}{$\operatorname{Exp}(B)$} \\
\hline & \multirow{4}{*}{ 4.50-5.00 (1 st Class) } & Intercept & & & & & & \\
\hline \multirow{23}{*}{2012} & & $\mathrm{OL}$ & .082 & 2.574 & .001 & 1 & .974 & 1.086 \\
\hline & & UTME & .684 & 1.485 & .212 & 1 & .645 & 1.982 \\
\hline & & PUTME & -2.012 & 3.009 & .447 & 1 & .504 & .134 \\
\hline & \multirow{4}{*}{ 1.00-1.49 (Pass) } & Intercept & 1.705 & 1.049 & 2.642 & 1 & .104 & \\
\hline & & $\mathrm{OL}$ & .136 & .658 & .043 & 1 & .837 & 1.145 \\
\hline & & UTME & -.378 & .441 & .734 & 1 & .392 & .685 \\
\hline & & PUTME & -.387 & .853 & .206 & 1 & .650 & .679 \\
\hline & \multirow{4}{*}{ 1.50-2.39 (3rd Class) } & Intercept & 1.809 & .940 & 3.709 & 1 & .054 & \\
\hline & & $\mathrm{OL}$ & .076 & .566 & .018 & 1 & .893 & 1.079 \\
\hline & & UTME & -.524 & .382 & 1.882 & 1 & .170 & .592 \\
\hline & & PUTME & .082 & .739 & .012 & 1 & .912 & 1.086 \\
\hline & \multirow{4}{*}{$2.40-3.49$ (2.2 Class) } & Intercept & 1.805 & .964 & 3.501 & 1 & .061 & \\
\hline & & $\mathrm{OL}$ & .703 & .579 & 1.474 & 1 & .225 & 2.021 \\
\hline & & UTME & -.769 & .395 & 3.789 & 1 & .052 & .464 \\
\hline & & PUTME & -.445 & .759 & .343 & 1 & .558 & .641 \\
\hline & & Intercept & 1.734 & 1.126 & 2.371 & 1 & .124 & \\
\hline & $350440\left(21 \mathrm{Clacs}^{3}\right.$ & $\mathrm{OL}$ & -.190 & .707 & .072 & 1 & .788 & .827 \\
\hline & $3.50-4.49$ (2.1 Class) & UTME & -1.400 & .495 & 8.003 & 1 & .005 & .247 \\
\hline & & PUTME & .309 & .923 & .112 & 1 & .738 & 1.362 \\
\hline & & Intercept & -1.971 & 2.353 & .702 & 1 & .402 & \\
\hline & $450-500(1 \mathrm{st} C \mathrm{l}$ ses & $\mathrm{OL}$ & 2.174 & 1.395 & 2.429 & 1 & .119 & 8.796 \\
\hline & 4.50-5.00 (1 st Class) & UTME & -20.124 & 0.000 & & 1 & & $1.822 \mathrm{E}-09$ \\
\hline & & PUTME & -1.626 & 1.873 & .754 & 1 & .385 & .197 \\
\hline & & Intercept & -.548 & 1.403 & .153 & 1 & .696 & \\
\hline & $100-10\left(\mathbf{P}_{9} \mathrm{sc}\right)$ & $\mathrm{OL}$ & .762 & .875 & .758 & 1 & .384 & 2.143 \\
\hline & $1.00-1.49$ (Pass) & UTME & .307 & .866 & .126 & 1 & .723 & 1.360 \\
\hline & & PUTME & -.279 & 1.132 & .061 & 1 & .806 & .757 \\
\hline & & Intercept & -.263 & 1.307 & .040 & 1 & .841 & \\
\hline & 15002000 & $\mathrm{OL}$ & .380 & .819 & .215 & 1 & .643 & 1.462 \\
\hline & $1.50-2.39$ (3rd Class) & UTME & .649 & .791 & .673 & 1 & .412 & 1.914 \\
\hline & & PUTME & .264 & 1.058 & .062 & 1 & .803 & 1.302 \\
\hline & & Intercept & .890 & 1.238 & .517 & 1 & .472 & \\
\hline 2013 & $240-30022 \mathrm{Clacs}$ & $\mathrm{OL}$ & .391 & .794 & .242 & 1 & .623 & 1.478 \\
\hline 2013 & $2.40-3.49$ (2.2 Class) & UTME & .248 & .790 & .099 & 1 & .753 & 1.282 \\
\hline & & PUTME & -.079 & 1.017 & .006 & 1 & .938 & .924 \\
\hline & & Intercept & .488 & 1.310 & .139 & 1 & .710 & \\
\hline & $350440\left(21 \mathrm{Cl}_{2 \mathrm{co}}\right.$ & $\mathrm{OL}$ & .152 & .839 & .033 & 1 & .856 & 1.165 \\
\hline & $3.50-4.49$ (2.1 Class) & UTME & .422 & .811 & .270 & 1 & .603 & 1.524 \\
\hline & & PUTME & .102 & 1.076 & .009 & 1 & .924 & 1.108 \\
\hline & & Intercept & -6.656 & 2.902 & 5.261 & 1 & .022 & \\
\hline & $450-500(1 \mathrm{st} C \mathrm{locs})$ & $\mathrm{OL}$ & 2.099 & 1.483 & 2.002 & 1 & .157 & 8.154 \\
\hline & 4.50-5.00 (1st Class) & UTME & 1.527 & 1.153 & 1.753 & 1 & .186 & 4.604 \\
\hline & & PUTME & -.462 & 1.802 & .066 & 1 & .798 & .630 \\
\hline & & Intercept & -.103 & 1.617 & .004 & 1 & .949 & \\
\hline & $100-10\left(\mathbf{P}_{9} \mathrm{sc}\right)$ & $\mathrm{OL}$ & -.071 & .878 & .007 & 1 & .935 & .931 \\
\hline & $1.00-1.49$ (Pass) & UTME & -.273 & .803 & .115 & 1 & .734 & .761 \\
\hline & & PUTME & .104 & 1.211 & .007 & 1 & .932 & 1.109 \\
\hline & & Intercept & 1.714 & 1.206 & 2.020 & 1 & .155 & \\
\hline & $150-20(3 \mathrm{rd} C l a c s)$ & $\mathrm{OL}$ & .188 & .660 & .081 & 1 & .776 & 1.207 \\
\hline & $1.50-2.39$ (3rd Class) & UTME & .084 & .579 & .021 & 1 & .885 & 1.087 \\
\hline & & PUTME & -.395 & .903 & .191 & 1 & .662 & .674 \\
\hline & & Intercept & 1.467 & 1.189 & 1.523 & 1 & .217 & \\
\hline 2014 & $240-349(2,2$ Class $)$ & $\mathrm{OL}$ & -.274 & .641 & .183 & 1 & .669 & .760 \\
\hline 2014 & $2.40-5.49$ (2.2 (rass) & UTME & -.590 & .577 & 1.045 & 1 & .307 & .554 \\
\hline & & PUTME & .561 & .887 & .400 & 1 & .527 & 1.753 \\
\hline & & Intercept & 1.773 & 1.252 & 2.007 & 1 & .157 & \\
\hline & $350-449(21$ Class $)$ & $\mathrm{OL}$ & -.596 & .682 & .765 & 1 & .382 & .551 \\
\hline & $3.50-4.49$ (2.1 Class) & UTME & -.752 & .632 & 1.417 & 1 & .234 & .471 \\
\hline & & PUTME & .584 & .941 & .385 & 1 & .535 & 1.793 \\
\hline & & Intercept & .421 & 1.832 & .053 & 1 & .818 & \\
\hline & & $\mathrm{OL}$ & .190 & 1.158 & .027 & 1 & .870 & 1.209 \\
\hline & $4.50-5.00$ (1 st Class) & UTME & .845 & .953 & .786 & 1 & .375 & 2.328 \\
\hline & & PUTME & -1.139 & 1.482 & .591 & 1 & .442 & .320 \\
\hline
\end{tabular}

Source: SPSS (2018). 
In Table 10, the traditional 0.05 criterion of statistical significance was also used. Each of the five equations for every academic session comprises of the intercept and the slope for the predictors. For all the academic sessions as shown on the results, the first equation intercept is the log of the ratio of the possibility of a student having a 'Pass' degree to the possibility of that student having a 'fail' degree. Among the classification of degrees, each of the CGPA categories is contrasted with the baseline group of 'Fail' degree.

For the students admitted during the 2010/2011 academic session, the slopes (B) of OL in all the CGPA categories are positive. These show that the relative strengths of their OL result performance on the CGPA categories of 'Pass', ' 3 rd Class', ' $2^{\text {nd }}$ Class Lower', ' $2{ }^{\text {nd }}$ Class Upper' and ' $1{ }^{\text {st }}$ Class' are higher than those with a CGPA category of 'Fail'. Furthermore, the slopes (B) of UTME in the CGPA categories of the ' $3{ }^{\text {rd }}$ Class' is negatively signifying that the relative strength of UTME is lower than those with a CGPA category of 'Fail' and the rest are positive which signifies otherwise. Conclusively, the slope (B) of PUTME in the CGPA category of ' $3{ }^{\text {rd }}$ Class' is positive and the rest negative. This indicates that the relative strength of UTME is higher than those with a CGPA category of 'Fail' and the rest of the CGPA categories are negative which indicates otherwise. The relative strength of OL, UTME and PUTME on CGPA performance of students admitted in the 2010/2011 session is not statistically significant except for the slope (B) of OL in the CGPA category of ' $2{ }^{\text {nd }}$ Class Upper', which is statistically significant.

As for the students admitted in the other sessions, 2011/2012 to 2014/2015, the relative strength of OL, UTME and PUTME on CGPA performance are statistically insignificant except for the slope (B) of UTME in the CGPA category of ' 2 nd $C$ lass Upper' and ' $1{ }^{\text {st }}$ Class' for those admitted in the 2012/2013 academic session, which is statistically significant.

\section{Conclusion}

The primary purpose of this study is to investigate if $\mathrm{OL}$ results, UTME and PUTME scores do predict the academic performance among first-year undergraduate students in the Faculty of Science. Based on the analysis and results using MLR and PPMC for each programme and each academic session, it is evident that OL, UTME or PUTME could not individually significantly predict the academic performance of students in Faculty of Science.

However, by combining all the criterion variables, that is OL, UTME, and PUTME, as one variable and performing the PPMC and MLR, findings show that OL is a good predictor on the dependent variable for academic performance with a weak correlation of 0.068 which is statistically significant at 0.04 level. This predictor holds true especially for students who are in the CGPA category of ' $2^{\text {nd }}$ Class Lower' and ' 1 st Class' respectively.
Although OL and UTME are still necessary as instruments for admission, it is recommended that the University be advised to include some other instruments such as senior secondary school mock examinations results for selecting candidates into any of the undergraduate degree programmes in the Faculty of Science. Also, there is a need to do a further study by including some more variables, such as age and senior secondary school mock examinations results, as criteria to significantly predict the academic performance of students successfully. The authors in [21], in their study also recommended the need of potential researchers to compare the OL, UTME and Post UTME terms and scores across Nigerian Universities for standardisation and a model for educational development in the twenty first century.

\section{References}

[1] M. O. Afu and I. B. F. Ukofia, 'Predictive Validity of UTME and Post-UTME Scores on first Year Students' Performance in four Departments in University of Abuja', International Journal of Education and Evaluation, vol. 3, no. 4, pp. 26-35, 2017.

[2] A. S. Magaji, S. Abdulkadir, A. Peter, A. A. Muhammad, and I. A. Yushau, 'An Evaluation of Students' Admission Exercises (ESAE) in Kaduna State University, Nigeria', International Journal of Educational Sciences, vol. 5, no. 2, pp. 131-135, 2013.

[3] P. Ayuba, 'Comparative Analysis of Post University Matriculation Examination in Nigerian Universities Using Fuzzy Logic', British Journal of Mathematics \& Computer Science, vol. 11, no. 6, pp. 1-10, Jan. 2015.

[4] N. J. Okoli, L. Ogbondah, and R. N. Ewor, 'The History and Development of Public Universities in Nigeria Since 1914', International Journal of Education and Evaluation, vol. 2, no. 1, pp. 60-73, 2016.

[5] D. Adesulu, 'NUC moves towards harmonised CGPA for varsities - Investigations', Vanguard News, Dec-2017.

[6] V. Ramesh, P. PArkavi, and K. Ramar, 'Predicting Student Performance: A Statistical and Data Mining Approach', International Journal of Computer Applications, vol. 63, no. 8, pp. 35-39, 2013.

[7] S. S. Olanipekun and J. K. Aina, 'Improving Students' Academic Performance in Nigerian Schools: The Role of Teachers', International Journal of Research in Humanities and Social Studies, vol. 1, no. 2, pp. 1-6, 2014.

[8] A. I. Joe, P. J. Kpolovie, K. E. Osonwa, and C. E. Iderima, 'Modes of admission and academic performance in Nigerian Universities', Merit Research Journal of Education and Review, vol. 2, no. 9, pp. 203-230, 2014.

[9] Usamah bin Mat, N. Buniyamin, P. M. Arsad, and R. Kassim, 'An overview of using academic analytics to predict and improve students' achievement: A proposed proactive intelligent intervention', presented at the IEEE 5th International Conference on Engineering Education (2013 ICEED), Selangor, Malaysia, 2013, pp. 126-130. 
[10] A. Kumar, 'Study of Academic Achievement, Values and Adjustment of Secondary School Students in Relation to Working Status of Mothers', PhD Thesis, Guru Nanak Dev University, Amritsar, 2010.

[11] A. O. Patrick, 'Three Years of Post UME Screening: Influence on Science Education Students' Achievement in Delta State University, Abraka', International Journal of Educational Science, vol. 2, no. 1, pp. 29-40, 2010.

[12] E. C. Eze, 'University Matriculation Examination as a Predictor of Students' Final Grades in the Faculty of Health Sciences and Technology of University of Nigeria, Nsukka', Master's Thesis, University of Nigeria, Nsukka, 2014.

[13] D. O. Igwue and O. Adikwu, 'Measurement of intellectual functioning of Nigerian youth: the predictive validity of JAMB/UME in relation to students' performance in University', Educational Research, vol. 3, no. 8, pp. 639-644, 2012.

[14] J. A. Odukoya et al., 'The Predictive Validity of University Admission Examinations: Case Study of Nigerian Unified Tertiary Matriculation Examination', Covenant International Journal of Psychology (CIJP), vol. 3, no. 1, pp. 1-10, 2018.

[15] B. A. Faleye, 'Predictive Validity of Students' Entry Qualifications into Mathematics Programme in Nigeria's Osun and Oyo States' Colleges of Education', Journal of Education and Human Development, vol. 4, no. 4, pp. 209-217, 2015.
[16] B. B. AINA, 'UTME and Post-UTME Scores as Predictor of Academic Performance of University Undergraduates of Adekunle Ajasin University, Akungba-Akoko, Ondo State, Nigeria', International Journal of Education and Evaluation, vol. 3, no. 1, pp. 37-43, 2017.

[17] P. J. Kpolovie, Advanced Research Methods. Owerri: Springfield Publishers, 2010.

[18] T. O. Adeyemi, 'The Effective use of Standard Scores for Research in Educational Management', Research Journal of Mathematics and Statistics, vol. 3, no. 3, pp. 91-96, 2011.

[19] A. Ahmad and S. Obiedat, 'Correlation and Prediction for Preparatory Year Math and Engineering Math in University of Hail', International Journal of Engineering Sciences \& Research Technology (IJESRT), vol. 6, no. 1, pp. 323-329, 2017.

[20] J. Starkweather and A. K. Moske, 'Multinominal Logistic Regression', 2011. [Online]. Available: https://it.unt.edu/sites/default/files/mlr_jds_aug2011.pdf. [Accessed: 11-Sep-2018].

[21] S. O. Uhunmwuangho and O. Ogunbadeniyi, 'The University Matriculation Examination as a Predictor of Performance in Post University Matriculation Examination: a Model for Educational development in the 21st Century', African Research Review, vol. 8, no. 1, pp. 99-111, 2014. 